\title{
DOI 10.26886/2414-634X.4(23)2018.12
}

\section{UDC: 261.7}

\section{THE DOCTRINE OF THE "RUSSIAN WORLD” IN THE CONTEXT OF POSTCOLONIAL STUDIES}

\section{A.V. Fomenko \\ National Pedagogical Dragomanov University, Ukraine, Kyiv}

The article examines the doctrine of the "Russian World» in the context of postcolonial studies. This direction of scientific thought sets itself the task of overcoming the consequences of the colonial dependence of the countries of the "East» from the "Western» metropolises. Postcolonial theory uses an original methodology based on the study of the liberation of colonial discourse from the narratives imposed by the metropolis. The application of this theory to the context of Eastern Europe is controversial, but considering the facts of Russia's political, cultural and ideological hegemony in the specified region with a certain degree of reservations it is deemed appropriate. Being a postmodern construct, the «Russian World» doctrine absorbs two key components of the previous ideological systems religious and linguistic identity. Relying on these components, it forms a new type of colonial dependence, in which Russia acts as a cultural and political metropolis. Changes in the sociopolitical context in the post-Soviet space which occurred after the Ukrainian Revolution of Dignity demonstrate the ineffectiveness of the doctrine of the «Russian World» as a colonial ideology.

Key words: Russian world, postcolonial theory, ideology, narratives, discourse, Russia, Ukraine, Orthodoxy.

Фоменко А. В. Доктрина "російського світу» в контексті постколоніальних досліджень / Національний педагогічний університет імені М. П. Драгоманова, Україна, Київ 
У статті розглянуто доктрину «Російського світу» в контексті постколоніальних досліджень. Зазначений напрямок наукової думки ставить перед собою завдання подолати наслідки колоніальної залежності країн «Сходу» від «Західних» метрополій. Постколоніалізм використовує оригінальну методологію, засновану на дослідженні процесу звільнення колоніального дискурсу від нав'язаних метрополією наративів. Застосування зазначеної теорії по відношенню до контексту Східної Європи $\epsilon$ спірним, однак, 3 огляду на фракти політичної, культурної та ідеологічної гегемонії Росії у вказаному регіоні, з певними обмовками визнається доречним. Будучи постмодерністським конструктом, доктрина «Російського світу» вбирає в себе два ключові компоненти попередніх ідеологічних систем - релігійну і мовну ідентичності. Спираючись на зазначені компоненти, вона формує новий тип колоніальної залежності, в якому Росія виступає в ролі культурної та політичної митрополії. Зміни соціально-політичного контексту на пострадянському просторі, що стали наслідком української Револючії Гідності, демонструють неефективність доктрини «Російського світу» як колоніальної ідеології.

Ключові слова: Російський світ, постколоніальна теорія, ідеологія, наративи, дискурс, Росія, Україна, православ'я.

Постановка проблеми. Для того, що б краще зрозуміти специфріку, пов'язану з процесами ґенези, актуалізації та рецепції доктрини «Російського світу», необхідно розглянути зазначений ідеологічний конструкт в контексті постколоніальних досліджень. Спираючись на зазначену методологію, ми зможемо зрозуміти витоки ідеології «Російського світу», дослідити процес їі конструювання і 
передбачити подальші перспективи використання зазначеної ідеологічної моделі.

Метою представленої статті $€$ дослідження доктрини «російського світу» в контексті постколоніальних досліджень.

Витоки постколоніальної теорії необхідно шукати в історикофілософрському контексті другої половини $\mathrm{XX}$ століття. Вона являє собою синтез методологічно і дисциплінарно гетерогенних, але тематично пов'язаних дискурсів, об'єднаних завданням подолання наслідків економічної, політичної і культурної залежності «не західного» світу від «західних» зразків і прототипів [3, с. 776]. Зазначена теорія використовує широкий спектр методів: постструктуралізм, психоаналіз, деконструкція, ідеї феміністичної критики [22, с. 160]. Діалектична за своєю суттю, вона будується на ряді ключових опозицій: «Схід-Захід», «колонія - митрополія», «пригноблений - гнобитель», «традиція модерн» [1]. У центрі досліджень - деконструкція колоніальних текстів. Колонія намагається пробитися крізь імперський диспозитив та впізнати саму себе в пропонованих їй наративах [3, с. 776].

Постколоніальна теорія розглядає три складові колоніального дискурсу: колоніалізм - антиколоніалізм - постколоніалізм. Іншими словами, це процес захоплення території - боротьба із загарбниками осмислення колоніального досвіду [там само]. Ключовим текстом даного напрямку досліджень прийнято вважати працю Едварда Саїда «Орієнталізм», опубліковану в 1979 році [3, с. 776; 22, с. 160]. У вказаній роботі автор піднімав проблематику взаємовідносин колонії і митрополії, приділяючи значну увагу питанню формування в дискурсі колонізаторів наративів про мешканців колонії. Цей процес тягне за собою подальшу трансляцію зазначених наративів на представників колонізованих народів і впливає на формування їх ідентичності [3, с. 776]. 
На ранньому етапі постколоніальна теорія акцентувала увагу на проблемах взаємин імперій західного зразка (Британія, Франція) з їх африканськими і азіатськими колоніями. Однак в 80-х роках XX століття поле постколоніальних досліджень було розширено. Причиною цього розширення став поступовий відхід від хибних уявлень про колоніальну єдність, що дозволило говорити про існування не однієї постколоніальної культури, а різних, які мають своє обличчя [22, с. 161]. Крім напрямку, заданого Едвардом Саїдом в рамках постколоніального дискурсу, на даний момент актуалізувалися два магістральні вектори досліджень: лінгвістичний, представлений роботами Гомі Бхабхі, та фреміністичний, представлений напрацюваннями Гаятрі Співак [22, с. 165-166].

Розширення поля постколоніальних досліджень дозволило включити в його контекст і колишні радянські країни. Цей процес піддався серйозній критиці з боку прихильників зазначеної теорії [13]. Основним об'єктом претензій $€$ співвіднесення імперського статусу Росії, а пізніше СРСР, з уявленням про «західний» тип колонізації, характерний для даного напрямку досліджень. На думку критиків, в пострадянському контексті складно говорити про серйозний культурний розрив між колоніями і митрополією. Виняток становлять лише країни Середньої Азії, рівень культурного розвитку яких до моменту колонізації їх Російською імперією істотно відрізнявся [1]. Критики вважають, що відсутність значного культурного розриву робить неможливим застосування звичної методології постколоніальної теорії до Східної Європи [там само].

3 іншого боку, згадана вище перспектива подолання узагальненого образу «Заходу» надає можливість включення пострадянського простору в контекст постколоніальних досліджень. Український дослідник Микола Рябчук вказує, що, незважаючи на відсутність 
глибокого культурного розриву, наявність фрактів лінгвістичної, етнічної, релігійної та соціальної дискримінації підкорених Росією народів дозволяє говорити про постколоніальний характер культур країн колишнього СРСР [13]. Ключовим елементом російської імперської моделі дослідник називає російську мову [там само]. Цей момент є особливо істотним, з огляду на важливість статусу мови в концепції «Російського світу» [4; 5]. Для того, щоб краще зрозуміти специфріку інтерпретації зазначеної доктрини в постколоніальному контексті, необхідно звернутися до розгляду двох ідеологічних прототипів зазначеної моделі - імперського та радянського.

Процес створення єдиної російської держави від самого початку був пов'язаний із активною міфотворчістю. Скинувши тягар ординської політичної залежності, Московія Івана III почала формувати власну політичну програму, офрормлену у вигляді доктрини «Москва - Третій Рим». За словами російського дослідника Бориса Успенського, в цьому проекті поєдналися дві тенденції - релігійна і політична. Перший аспект включав в себе візантійську ідею «релігійної чистоти», за якою Росія та іiї правителі позиціонувалися як «охоронці православ'я». Другий аспект підкреслював імперський статус, виправдовуючи цим політику розширення територій нової держави [17, с. 125-126]. Православ'я ставало «клеєм», який з'єднував імперську ідею і колоніальну політику. Подальша російська історія продемонструвала якість такого поєднання релігії та політики, яке трансформувалося в тріаду «православ'ясамодержавство-народність» і проіснувало до 1917 року. Російська революція завершила історією «православної Русі», продемонструвавши несумісність вказаного фрормату ідеології 3 поточними соціально-політичними реаліями, обумовленими переходом до доби модерну. 
Перед владою більшовиків стояло важливе завдання - створення нового імперського наративу, який би одночасно поєднував риси есхатологічного утопізму, ізоляціонізму і колоніалізму. За словами американської дослідниці Лори Адамс, розроблена більшовиками колоніальна модель істотно відрізнялася від західних аналогів принципом взаємодії між перифрерією і центром. Спираючись на зовні «лівий» наратив про «дружбу народів», класову рівність і солідарність, радянська влада проводила внутрішньо «праву» централізовану колоніальну політику [1]. Дослідник Микола Рябчук вказує, що головним інструментом цієї політики виступала російська мова, через яку транслювалася російська культурна ідентичність [13]. Ідеологія СРСР формувала нову ідентичність, в рамках якої всі національні культури народів Країни Рад заочно записувалися в «молодші брати» «великого російського народу», а їхні культури і мови позиціонувалися як компоненти нової радянської (по фракту - великоруської) культури [там само]. Якщо у випадку з ідеологією Російської імперії «клеєм» було православ'я, то в атеїстичної радянської ідеології ним виступав 3 одного боку декларативний соціалізм, а з іншого - мовна та культурна ідентичності.

Чергові трансформації в світовому соціально-політичному контексті, обумовлені переходом від модерну до постмодерну, стали серйозним випробуванням для радянського колоніального проекту. Звісно, за процесом розпаду СРСР стояла низка важливих економічних і соціальних чинників, однак, варто визнати, що провідною ідеологічною передумовою завершення «соціального експерименту» стала невідповідність міфології актуальним соціокультурним викликам [16, с. 147]. Жорстокий удар по ідеології СРСР завдала напруга між культурою «суспільства споживання», яка транслювалася Заходом, та реаліями продовольчих дефіцитів кінця радянської епохи. Радянські 
люди все менше хотіли жити заради побудови соціалізму та все більше прагнули долучитися до загальносвітових стандартів споживання [6, с.14-15]. Знецінення радянської ідеологічної моделі спровокувало ситуацію світоглядного вакууму, який швидко заповнювався загальнонаціональним почуттям ресентименту [7]. Особливо болісно ресентимент відчували мешканці пострадянської Росії, яка втратила статус імперського центру. Багато в чому це відчуття підживлювалось не лише крахом імперського проекту, а скоріше «приниженим» статусом російської культури і мови. Цей момент багато в чому обумовлював живу реакцію росіян на скорочення використання російської мови в прибалтійських, середньоазійських республіках і Україні [2, с. 50].

Владі РФ було необхідно розробити нову ідеологічну програму, здатну використовувати потенціал «російського ресентименту» для відродження імперського проекту. Відповіддю на цей запит стало створення пілотної версії ідеологічної доктрини «Російського світу», розробленої в рамках так званого Московського методологічного гуртка на чолі з Петром Щедровицьким. Український дослідник архімандрит Кирило (Говорун) вказує: «Згідно з припущенням розробників доктрини, російська мова може бути зв'язком з батьківщиною для тих росіян, які емігрували після розпаду Радянського Союзу. Мова організовує їх в інтелектуальну мережу - без єдиного центру і без чіткої політичної програми» [5].

Розроблена московськими методологами концепція була взята на озброєння російськими націоналістичними і клерикальними колами, зусиллями яких до неї були включені націоналістичні та релігійні компоненти [4]. Результатом цього синтезу став новий ідеологічний конструкт в центрі якого знаходилася ідея повернення до імперського проекту, заснованого на створенні нової моделі ідентичності, 
складовими компонентами якої ставали російська мова, російська культура та православ'я [4; 5]. Таким чином, доктрина «Російського світу» поєднувала в собі два ключових компоненти імперської та радянської ідеології - релігійну і мовну ідентичності. В якомусь сенсі, вона задавала нові світоглядні критерії: «росіянином», відповідно до логіки ідеологів доктрини, вважався той, хто сповідує православ'я, розмовляє російською мовою або відчуває симпатію до російської культури [4].

Посилення російського політичного режиму з приходом до влади Володимира Путіна сприяло наростанню нового колоніального потенціалу в сучасній РФ. У певному сенсі основою цього потенціалу ставала популярна в перше десятиліття XXI століття геополітика з ії концепцією «зон впливу», популяризатором якої виступав Олександр Дугін [4]. У свідомості російської політичної еліти сформувалося стійке уявлення про право Росії створити власну «зону впливу», простором якої вважалася територія всього колишнього СРСР [15]. 3 огляду на поточний загальносвітовий політичний контекст, ідеологи «Російського світу» вважали доцільнішим діяти не безпосередньо, а використовувати «м'які» методи поширення нової імперської програми. Допоміжною силою путінського режиму виступила Російська православна церква з їі розгалуженою єпархіальною і парафіяльною мережами. Тут варто зробити важливе уточнення: ще наприкінці 1990-х ідеологія «Російського світу» була активно підтримана тодішнім головою Відділу зовнішніх церковних зносин РПЦ митрополитом Смоленським та Калінінградським Кирилом (Гундяєвим) [4; 18, с. 12]. Після свого обрання на пост московського патріарха, Кирило перетворив зазначену концепцію на магістральний риторичний тренд та став головним лобістом «Російського світу» $[18$, с. 12]. У громадському дискурсі зазначена доктрина була популяризована за 
допомогою майданчиків Російського народного собору, який також проходив під егідою РПЦ [5].

Починаючи з моменту обрання митрополита Кирила (Гундяєва) на посаду патріарха, доктрина «Російського світу» почала активно поширюватися у внутрішньоцерковному дискурсі. Ще будучи главою ВЗЦЗ, Кирило під час виступу в Києві окреслив гіпотетичний простір «Святої Русі», до якого, крім Росії, були включені Білорусь і Україна [8]. Пізніше до них додалися Молдова і Казахстан [10; 14]. Варто відзначити, що принципи, на яких базувалася ця концепція, багато в чому будувалися не лише на ідеї повернення до колишніх імперських кордонів (включення в сферу впливу РФ колишнього радянського простору), а й розширенні цього впливу на загальносвітовий простір. Для цього патріархом Кирилом та іншими спікерами РПЦ, зокрема протоієреєм Всеволодом Чапліним, активно використовувалася антиглобалістська риторика [9; 20]. Завдяки мобілізації «незгодних» по всьому світу ідеологи «Російського світу» планували створити міжнародну мережу прихильників, за допомогою яких би здійснювався вплив на світову політику. На думку російської дослідниці Олени Волкової, апелюючи до мовної, культурної та релігійної ідентичностей, критикуючи «Захід» і лібералізм, Кирило й інші популяризатори концепції «Російського світу» пропонували створити міжнародну мережу прихильників, порівнянну з комуністичним інтернаціоналом, яка повинна була стати своєрідною платформою для проведення подальшої загарбницької політики у світових масштабах [4].

«Проблемною точкою» російського колоніального проекту традиційно вважалася Україна. Невдалі спроби вийти із зони політичного впливу імперії, закріпачення селянства, принижений статус мови і культури сфрормували в українському соціокультурному дискурсі оригінальну форму ресентименту, яка знайшла своє відображення в 
класичній українській літературі. 3 іншого боку, такий стан речей сприяв фрормуванню особливого напряму критики російської колоніальної політики, яку можна порівнювати 3 антиколоніальною критикою літератур народів Сходу [13]. Варто зазначити, що ключовим вектором цієї критики стало подолання стереотипів про локальність української культури [3, с. 776]. Процес відходу від локального культурного статусу багато в чому збігався з поступовим звільненням від російської політичної залежності. Здобуття Україною власної державності в 1991 році ідеологічно збігалося 3 подоланням традиційного (імперського) і модерністського (радянського) міфрів. Однак українське суспільство явно не було готове до повернення імперського міфу в його постмодерністській інтерпретації (доктрина «Російського світу»), яка активно просувалася в українському інформаційному просторі, починаючи 3 візиту до Києва тоді ще митрополита Кирила (Гундяєва) в 2008 році [8]. Важливо відзначити, що тодішній візит майбутнього московського патріарха збігся 3 відвідуванням Києва влітку 2008 Вселенським патріархом Варфоломієм, при зустрічі з яким президент Віктор Ющенко обговорював перспективи створення помісної української православної церкви [11].

Звісно, в українському соціально-політичному дискурсі була присутня критика доктрини «Російського світу», але ця критика не виходила за рамки наукового і релігійного контекстів. Переломний момент відбувся разом із політичною кризою кінця 2013 року, яка спричинила Революцію Гідності і подальші події, включно з війною на Сході України. Майдан став своєрідним «лакмусовим папірцем», який виявив неефективність нової імперської міфології. Українське суспільство наочно продемонструвало небажання бути об'єктом нової імперської політики, кінцевою метою якої мало стати включення країни 
в сореру геополітичних інтересів Росії, до так званого Митного союзу [15]. Результатом цих процесів стало зростання в українському суспільстві інтересу до осмислення концепції «Російського світу». Зазначена доктрина, яку більшість українців сприйняло як ідеологію ворога, протягом 2014-2018 років перетворилася на своєрідну «точку рефреренції», по відношенню до якої вибудовувалася нова модель масової української самосвідомості. Методом від супротивного українці почали визначати себе як спільнота тих, хто не належить до «Російського світу», спільнота з відмінними етичними й естетичними орієнтирами. 3 огляду на це можна констатувати фракт відмежування від імперського диспозитиву, з його нав'язаним уявленням про власну ідентичність. Однак, при наявних мовних та культурних відмінностях, своєрідним «каменем спотикання» нової ідентичності ставала загальна релігійна традиція. Ця ситуація знову актуалізувала питання про створення єдиної помісної української православної церкви.

Соціально-політичні трансформації після подій Майдану зумовили й серйозну зміну в риториці і внутрішній політиці Української православної церкви Московського патріархату. Одіозні священики, що проповідували ідеї «Російського світу», були звільнені 3 керівних церковних посад або втекли до Росії [21]. Офіційне церковне керівництво з 2014 року починає відхрещуватись від зв'язку УПЦ 3 концепцією «Російського світу» [19]. Такий поворот був значною мірою обумовлений неоднозначним статусом зазначеної православної церкви. Через канонічне підпорядкування Москві, вона фрактично залишається «останнім бастіоном» російської ідентичності в Україні.

Висновки. 3 огляду на описані вище процеси трансформації української ідеології, можемо констатувати, що саме російське православ'я, представлене структурою УПЦ (МП), на даний момент є «останньою зачіпкою» російського колоніального проекту в Україні. 
Створення паралельної канонічної церковної структури, якою, за логікою своїх апологетів, повинна стати визнана світовим православ'ям єдина автокефальна українська церква, не тільки суттєво підірве позиції РПЦ, але і позбавить Росію останнього важеля впливу на український соціальний, релігійний та політичний контекст [12]. Ця перспектива дозволяє говорити про перехід до завершальної фрази російського колоніального проекту, що відкриває значні дослідницькі перспективи перед українським науковим співтовариством. Завершення процесу антиколоніальної боротьби створює всі умови для початку постколоніальних досліджень, коли буде детально проаналізовано російський колоніальний дискурс і його результатом стане переосмислення колоніального минулого. Ця перспектива задає новий вектор для подальших наукових досліджень

\section{תimepamypa:}

1. Адамс Л. Применима ли постколониальная теория к Центральной Евразии? [Електронний ресурс] / Лора Адамс // Журнальный зал. 2009. - Режим доступу: http://magazines.russ.ru/nz/2009/4/am5.html.

2. Арефььев А. Л. Русский язык на рубеже XX-XXI веков / Александр Леонардович Арефьев. - М.: Центр социального прогнозирования и маркетинга, 2012. - 482 с.

3. Бобков И. М. Постколониальные исследования / Игорь Михайлович Бобков // Новейший фрилософский словарь / Игорь Михайлович Бобков. - Минск: Книжный дом, 2003. - С. 776-777.

4. Волкова Є. ІӘеологія «русского мира» як релігія війни [Електронний ресурс] / Єлена Волкова // Збруч. - 2016. - Режим доступу: https://zbruc.eu/node/51719. 
5. Говорун К. Интерпретируя "русский мир" [Електронний ресурс] / Кирилл Говорун // Русский журнал. - 2014. - Режим доступу: http://www.russ.ru/Mirovaya-povestka/Interpretiruya-russkij-mir.

6. Ильин В. И. Общество потребления: теоретическая модель и российская реальность / Владимир Иванович Ильин // Мир России. 2005. - №2. - C. 3-40.

7. Медведев С. Русский ресентимент [Електронний ресурс] / Сергей Медведев // Журнальный зал. - 2014. - Режим доступу: http://magazines.russ.ru/oz/2014/6/3m.html.

8. Митрополит Кирилл на концерте в Киеве призвал к духовному единству [Електронний ресурс] // РИА Новости. - 2008. - Режим доступу: https://ria.ru/religion/20080727/114995505.html

9. Митрополит Кирилл. Норма веры как норма жизни [Електронний ресурс] / Митрополит Кирилл // Независимая газета. - 2000. - Режим доступу : http://www.ng.ru/ideas/2000-02-16/8_norma.html.

10. Предстоятель Русской Церкви призвал укреплять казачью солидарность на всем пространстве Святой Руси [Електронний ресурс] // Официальный сайт Московского Патриархата. - 2010. Режим доступу : http://www.patriarchia.ru/db/text/1265739.html.

11. Президент Украины попросил Патриарха Варфоломея помочь 8 создании единой поместной православной Церкви [Електронний ресурс] // News.ru.com. - 2008. - Режим доступу: https://www.newsru.com/religy/26jul2008/ugh.html.

12. Расков С. Открытая угроза: украинская автокефалия и рогатки «русского мира» [Електронний ресурс] / Сергей Расков // Хвиля. 2018. - Режим доступу: http://hvylya.net/analytics/politics/otkryitayaugroza-ukrainskaya-avtokefaliya-i-rogatki-russkogo-mira.html. 
13. Рябчук М. Україна - не Афррика. Але що? [Електронний ресурс] / Микола Рябчук // Збруч. - 2013. - Режим доступу: https://zbruc.eu/node/10508.

14. Святейший Патриарх Кирилл: Молдова - неотъемлемая часть Святой Руси [Електронний ресурс] // Офрициальный сайт Московского Патриархата. - 2010. - Режим доступу: http://www.patriarchia.ru/db/text/1254808.html.

15. Тимофреев А. "Русский мир" и "русская война" [Електронний ресурс] / Александр Тимофреев // Иарекс. - 2015. - Режим доступу: http://www.iarex.ru/articles/51602.html.

16. Туманов Д. Журналистика периода постмодерна: глобализация vs индивидуализация / Д. Туманов, Л. Егорова. // БДУ. - 2016. - С. 145150.

17. Успенский Б. А. Избранные труды. Семиотика истории. Семиотика культуры / Борис Андреевич Успенский. - М.: Школа «Языки русской культуры», 1996. - 608 с.

18. Филатов С. Патриарх Кирилл - два года планов, мечтаний и неудобной реальности / Сергей Филатов // Православная церковь при новом патриархе / Сергей Филатов. - М.: РОССПЭН, 2012. (Российская политическая энциклопедия). - (Религия в Евразии). - С. $9-69$.

19. Хоменко С. Украинская православная церковь никакого отношения к «русскому миру» не имеет - архиепископ УПЦ [Електронний ресурс] / С. Хоменко, В. Шрамович // BBC News. - 2018. - Режим доступу: https://www.bbc.com/ukrainian/features-russian44067206.

20. Чаплин В. Ценности веры, святынь, Отечества - выше прав человека [Електронний ресурс] / Всеволод Чаплин // Правозащитный 
центр Всемирного русского народного собора. - 2011. - Режим доступу: http://pravovrns.ru/?p=4797

21. Щеткина Е. Батюшки из УПЦ начали бежать в Россию [Електронний ресурс] / Екатерина Щеткина // Деловая столица. 2014. - Режим доступу: http://www.dsnews.ua/society/batyushki-iz-uptsmp-nachali-bezhat-v-rossiyu-11062014020500.

22. Юрчук Е. А. Теоретические аспекты постколониальных студий / Елена Алексеевна Юрчук // Вестник МГЛУ. - 2013. - №3. - С. 161166.

\section{References:}

1. Adams L. Primenima li postkolonialnaya teoriya $k$ Tsentralnoy Yevrazii? [Elektronnyj resurs] / Lora Adams // Zhurnalnyy zal. - 2009. - Rezhym dostupu : http://magazines. russ.ru/nz/2009/4/am5.html.

2. Arefev A. L. Russkiy yazyk na rubezhe XX-KhKhl vekov / Aleksandr Leonardovich Arefev. - M.: Tsentr sotsialnogo prognozirovaniya $i$ marketinga, 2012. - $482 \mathrm{~s}$.

3. Bobkov I. M. Postkolonialnye issledovaniya / Igor Mikhaylovich Bobkov/l Noveyshiy filosofskiy slovar / Igor Mikhaylovich Bobkov. - Minsk: Knizhnyy dom, 2003. - S. 776-777.

4. Volkova E. Ideologiya "russkogo mira» yak religiya viyni [Elektronnyj resurs] / Elena Volkova // Zbruch. - 2016. - Rezhym dostupu: https://zbruc.eu/node/51719.

5. Govorun K. Interpretiruya "russkiy mir" [Elektronnyj resurs] / Kirill Govorun // Russkiy zhurnal. - 2014. - Rezhym dostupu: http://www.russ.ru/Mirovaya-povestka/Interpretiruya-russkij-mir.

6. Ilin V. I. Obshchestvo potrebleniya: teoreticheskaya model i rossiyskaya realnost / Vladimir Ivanovich Ilin // Mir Rossii. - 2005. - №2. - S. 3-40. 
7. Medvedev S. Russkiy resentiment [Elektronnyj resurs] / Sergey Medvedev // Zhurnalnyy zal. - 2014. - Rezhym dostupu: http://magazines.russ.ru/oz/2014/6/3m.html.

8. Mitropolit Kirill na kontserte $v$ Kieve prizval $k$ dukhovnomu edinstvu [Elektronnyj resurs] // RIA Novosti. - 2008. - Rezhym dostupu: https://ria.ru/religion/20080727/114995505.html

9. Mitropolit Kirill. Norma very kak norma zhizni [Elektronnyj resurs] / Mitropolit Kirill // Nezavisimaya gazeta. - 2000. - Rezhym dostupu: http://www.ng.ru/ideas/2000-02-16/8_norma.html.

10. Predstoyatel Russkoy Tserkvi prizval ukreplyat kazachyu solidarnost na vsem prostranstve Svyatoy Rusi [Elektronnyj resurs] // Ofitsialnyy sayt Moskovskogo Patriarkhata. - 2010. - Rezhym dostupu: http://www.patriarchia.ru/db/text/1265739.html.

11. Prezident Ukrainy poprosil Patriarkha Varfolomeya pomoch $v$ sozdanii edinoy pomestnoy pravoslavnoy Tserkvi [Elektronnyj resurs] // $\begin{array}{lllll}\text { News.ru.com. } & - & 2008 . & - & \text { Rezhym dostupu: }\end{array}$ https://www.newsru.com/religy/26jul2008/ugh.html.

12. Raskov S. Otkrytaya ugroza: ukrainskaya avtokefaliya i rogatki «russkogo mira» [Elektronnyj resurs] / Sergey Raskov // Khvilya. - 2018. Rezhym dostupu : http://hvylya.net/analytics/politics/otkryitaya-ugrozaukrainskaya-avtokefaliya-i-rogatki-russkogo-mira.html.

13. Ryabchuk M. Ukraïna - ne Afrika. Ale shcho? [Elektronnyj resurs] / Mikola Ryabchuk // Zbruch. - 2013. - Rezhym dostupu: https://zbruc.eu/node/10508.

14. Svyateyshiy Patriarkh Kirill: Moldova - neotemlemaya chast Svyatoy Rusi [Elektronnyj resurs] // Ofitsialnyy sayt Moskovskogo Patriarkhata. 2010. - Rezhym dostupu: http://www.patriarchia.ru/db/text/1254808.html. 
15. Timofeev A. "Russkiy mir" i "russkaya voyna" [Elektronnyj resurs] / Aleksandr Timofeev // lareks. - 2015. - Rezhym dostupu: http://www.iarex.ru/articles/51602.html.

16. Tumanov D. Zhurnalistika perioda postmoderna: globalizatsiya vs individualizatsiya / D. Tumanov, L. Yegorova // BDU. - 2016. - S. 145-150. 17. Uspenskiy B. A. Izbrannye trudy. Semiotika istorii. Semiotika kultury / Boris Andreevich Uspenskiy. - M.: Shkola "Yazyki russkoy kultury», 1996. $-608 s$.

18. Filatov S. Patriarkh Kirill - dva goda planov, mechtaniy i neudobnoy realnosti / Sergey Filatov // Pravoslavnaya tserkov pri novom patriarkhe / Sergey Filatov. - M.: ROSSPEN, 2012. - (Rossiyskaya politicheskaya entsiklopediya). - (Religiya v Yevrazii). - S. 9 - 69.

19. Khomenko S. Ukrainskaya pravoslavnaya tserkov nikakogo otnosheniya $k$ «russkomu miru» ne imeet - arkhiepiskop UPTs [Elektronnyj resurs] / S. Khomenko, V. Shramovich // BBC News. - 2018. - Rezhym dostupu: https://www.bbc.com/ukrainian/features-russian-44067206.

20. Chaplin V. Tsennosti very, svyatyn, Otechestva - vyshe prav cheloveka [Elektronnyj resurs] / Vsevolod Chaplin // Pravozashchitnyy tsentr Vsemirnogo russkogo narodnogo sobora. - 2011. - Rezhym dostupu: http://pravovrns.ru/?p=4797

21. Shchetkina Ye. Batyushki iz UPTs nachali bezhat $v$ Rossiyu [Elektronnyj resurs] / Yekaterina Shchetkina // Delovaya stolitsa. - 2014. Rezhym dostupu: http://www.dsnews.ua/society/batyushki-iz-upts-mpnachali-bezhat-v-rossiyu-11062014020500.

22. Yurchuk Ye. A. Teoreticheskie aspekty postkolonialnykh studiy / Yelena Alekseevna Yurchuk // Vestnik MGLU. - 2013. - №3. - S. 161-166. 